same people as close neighbours during the whole of that time (whence some of the attraction of Moscow and the other large cities)

It is asking more of flesh and blood (not to mention mind) than they can bear to expect that everyone can live happily, and remain creative, in such circumstances. Small disputes grow into entrenched quarrels with the passage of time, just as friendly competition may be magnified into envious rivalry as success turns out to be distributed unevenly. Playing laboratory politics may become not merely a sport but a means of survival. Especially in the smaller institute towns, the determination to survive is fortified by the knowledge that finding another job in the locality will be difficult.

The result, inevitably, is that institutes carry on their books many people who have long since gone to sleep. Quantitative estimates are of course impossible, but institute directors estimate the proportion of sleepers at their own laboratories at between 10 and 30 per cent, sometimes venturing ominously that it may be much greater elsewhere.

The giveaway here is not the great size of many Soviet institutes, which is often a consequence of their need to be selfcontained enough to make their own research materials, but what people at all except the highest level in the hierarchy have said in open conversation; they name the people, describe how they fill their days, protest that many of them practise "false science" (a word for the kind of work that could not be defended at an open colloquium) and, charitably, add that they sympathize with the reasons why those named cannot be dismissed. There is nowhere for them to go, or to live when they get there.

So, if you are from the West, think of the Soviet research institute as if it were a ship sailing on an endless ocean. Its complement of passengers changes when some occasionally get off and others join. From time to time, some passengers even learn to sail the ship. Everybody knows the destination ("Make thermonuclear fusion economic", or something like that), and knows how far away it is. How do you spend your time? On science, or at beating the other fellow at bridge?

The academy will be deeply hurt at this complaint, which it will say is subjective (which is true). But the observation derives from a great many conversations with people at a score of academy institutes. Some institutes are in good shape; others seem to dissipate their collective energy on battles within their walls. That is not surprising; the same would happen whenever people were bound together so vicariously, and for so long, whence the reference to Anna Karenina. But the practice seems peculiar to the Soviet Union and to China.

\title{
Must the young carry all the weight?
}

THE youngest institute people have the hardest time. Typically, they will have first entered their institute after their third undergraduate year and will have done well enough (half do not) to be kept on for the usual three-year stint working for the degree of cadidate of science (the Soviet equivalent of a $\mathrm{PhD}$ ).

Although a proportion, usually again a half of those graduating at this level (but there is no way of telling in advance what the numbers will be), are sent to the figurative Siberia of a ministry institute.

The lucky ones kept on (who, if male, will be 27 years or older, allowing for two years of military service) must look forward to several years of personal deprivation. Starting salaries are 125 rubles a month, no more than research students' stipends in fields such as mathematics and physics. But the next step on the academic ladder, the DSc by thesis which allows a person to qualify as a professor of an associated university, is not usually reached until a person's late thirties or early forties.

In the circumstances, it is mystifying that younger members of institutes do as much good work as is apparent. Marriage becomes an economic and social necessity (for the sake of a second, often greater, salary and the chance of an apartment rather than a hostel bed).

But at this stage, children can be a great misfortune. One married couple, with appointments at different institutes and now saddled with a child for whom they must care in a one-room apartment, take turn and turn about at showing up at work, one in the morning and one in the afternoon.

A young person's advancement in these early years depends crucially on his or her laboratory chief, many of whom are able to bring out the best in junior colleagues. But laboratory chiefs sometimes take against the people they have chosen a few years earlier, assigning them the most tedious tasks or keeping them on low salaries. Most people at this stage of their careers take in translation or abstracting work if they can; teaching, the rates for which have recently been doubled, can bring in more than 10 rubles for a twohour stint (but is usually in the gift of the laboratory chief).

Working women have the rough edge of the marriage bargain. Their husbands, even if they share the view that children would be a misfortune, still expect them to shop for food, a matter of standing endlessly in line, often during working hours.

The climate is something else again, in most of the Soviet Union. So too is the lack of personal (as distinct from public) transport. Institute people are lucky about vacations, with up to six weeks in a year (but a couple of weeks for two at the Black Sea can cost 1,000 rubles). The mystery is not that they do so little but, in the circumstances, so much.

\section{Shemiakin Institute}

\section{Biotechnology's palace in the sun}

THOSE who believe all Soviet researchers to be ill-equipped should disabuse themselves by visiting the Shemiakin Institute of Bio-Organic Chemistry, in an inner Moscow suburb. The institute is identifiable by the sculpture of the valinomycin molecule alongside the entrance to the administration block, one of four sevenstorey hollow cubes joined together at their corners.

The buildings and its contents have cost $\$ 150$ million in 10 years, more than half of that in 'currency'. The money shows. The building itself is a startling departure from the starkness of Moscow's monolithic apartment and office blocks. One academician complained at a meeting earlier this year that the sculpture cost more than the research it commemorates.

The interior, by Finnish and Yugoslav contractors, is luxuriously appointed; the floors of the administration block not covered in wall-to-wall carpeting are simple marble. Elsewhere, there are laboratory corridors with red Asian runners down the centre. The council meetingroom, dark wood with tables to match, would make a boardroom for a multinational from the West. The principal auditorium, with over-stuffed tip-back seats in apple green, might be a luxury cinema were the seats less steeply raked.

For the rest, the institute building has a computer centre, a series of pilot plants, a block in which experiments with radioactivity are concentrated and a healthcare centre for the staff. Working laboratories are neat and well-constructed, usually in pairs with connecting offices against the external walls (and cold rooms and the like in the dead spaces). Much of the equipment carries labels that should be familiar from the advertisement pages of Nature. An internal greenhouse in a connecting internal corridor doubles as a phytotron and decoration.

Physically, the laboratories are better than the best in the West, but emptier. Genentech's workforce in San Francisco, housed in what is by comparison a rabbithutch, might go on strike after a sight of the new Shemiakin Institute.

That is probably now misnamed, although many of the 220 qualified people 